\title{
Oleuropein using as an Additive for Feed and Products used for Humans Fügen DURLU-ÖZKAYA ${ }^{1 *}$ and Mücahit Taha ÖZKAYA ${ }^{2}$
}

${ }^{1}$ Gazi University, Tourism Faculty, 06830, Gölbasi, Ankara, Turkey

${ }^{2}$ Ankara University, Agriculture Faculty, Department of Horticulture, 06110, Diskapi, Ankara, Turkey

\begin{abstract}
Olive tree has been accepted as a symbol of holiness, abundance, wisdom and health, for centuries. Although its fruit is mainly used as a food after processing for table olive and olive oil, it is used for preparing medical products, cosmetic and animal feed. Olive trees have been cultivated for thousands of years, but the immune and circulatory benefits of olive leaf have only recently become fully realized. Olive leaf was first used medicinally in Ancient Egypt and was a symbol of heavenly power. There are many invivo and invitro researhes has been done on the effects of Oleuropein, one of the most important phenolic compound extracted from olive leaves, on health. The effects of the olive tree, accepted as an elixir of health and especially its product Oleuropein on human health and as an additive for animal feeds.
\end{abstract}

Keywords: Olive leaf; Oleuropein; Human health; Animal feed

\section{Introduction}

Olive tree (Olea europaea L.), its wood, fruit, leaves, roots and bark contain oleuropein, a non-toxic secoiridoid. It is a phenolic compound which has been shown to possess diverse healing properties for its vasodilatory [1], hypotensive [2,3], anti-inflamatory [4], antirheumatic [5], diuretic [6], anti-atherogenic [7] and antipyretic [8] effects. Most of these pharmacologic features of oleuropein (Figure 1) are due to its potent antioxidant action [9].

Oleuropein appears to be present throughout the olive tree parts. Amoung them olive leaves contain around 60 90 mg per gram (dry weight) oleuropein, additionaly significant levels of a glucosidic ester of elenolic acid and hydroxytyrosol (3, 4-dihydrophenylethanol). However, it turns out that oleuropein and the products of its hydrolysis, oleuropein aglycone, elenolic acid, beta-3,4-dihydroxyphenyethyl alcohol and methyl-o-methyl elenolate, are the major molecules of interest biologically.It is known that the leaves contain secoiridoids including oleuropein, as well as ligustroside and oleacein. It further contains triterpenoids (oleanolic acid and uvaol), sterols, flavonoids (chrysoeriol, apigenin and luteolin glycosides) and various other phenolic acids [10].

Olive tree is native to Asia Minor and Syria, but is cultivated in all Mediterranean countries as well as in Chile, Peru and South Australia, USA $[11,12,13]$. Olive trees have been cultivated for thousands of years, but the immune and circulatory benefits of olive leaf (besides the olive oil) have only recently become fully realized. Olive leaf was first used medicinally in Ancient Egypt and was a symbol of heavenly power. More recent knowledge of the olive leafs medicinal properties dates back to the early 1800 s when pulverised leaves were used in a drink

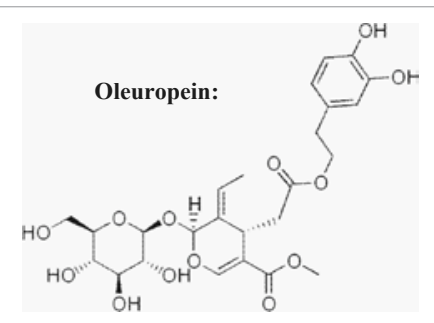

Figure 1: Chemical form of oleuropein. to lower fevers. A few decades later, green olive leaves were used in tea as a treatment for malaria [15]. Numerous scientific studies have been added to investigate the extract's beneficial properties, and olive leaf extracts are suggested as dietetic products and/or food integrators [14]. Olea europaea preparations have been started to use widely in folk medicine in European Mediterranean area, Arabia peninsula,India and other tropical and subtropical regions, as diuretic, hypotensive, emollient and for urinary and bladder infections [15].

The traditional Mediterranean diet consists of vegetables, fruits, legumes, cereals and fish. Olive oil also represents an important component of the Mediterranean diet whose intake is greatly growing in developed and developing countries for its known healing effects. $[5,16,17,18,19,20]$. In the current review, it is highlighted on traditional medicinal uses of Olea europaea, it's using as an additive for feed and used for the humans.

\section{Traditional medicinal uses of oleuropein for human}

Most of the plant parts of Olea europaea are used in traditional system of medicine in the world. Olive oil is mixed with large quantities of lemon juice to treat gallstones. However; there is one case report in which treatment with olive oil and lemon juice resulted in the passage of numerous gallstones, as demonstrated by ultrasound examination [10]. Leaves are taken orally for stomach and intestinal diseases and used as mouth cleanser [21]. A hot decoction of the dried olive fruit and of dried leaf is taken orally for diarrhoea and to treat respiratory and urinary tract infections [10]. Hot water extraction of the fresh leaves is taken orally to treat hypertension and to induce diuresis [2]. Seed oil is taken orally as a cholagogue, to remove gall stones, in nephritis associated with the lead intoxication [22]. To prevent hair loss, oil is applied every night on the scalp then washed the next morning [10].

*Corresponding author: Fügen DURLU-ÖZKAYA, Gazi University, Tourism Faculty, 06830, Gölbasi, Ankara, Turkey, Tel: +90 312 4851460/352; Fax: +90 312 3266273; E-mail: fugen@gazi.edu.tr, fdozkaya@hotmail.com

Received December 16, 2010; Accepted May 10, 2011; Published May 15, 2011

Citation: DURLU-ÖZKAYA F, ÖZKAYA MT (2011) Oleuropein using as an Additive for Feed and Products used for Humans. J Food Process Technol 2:113. doi:10.4172/2157-7110.1000113

Copyright: (C) 2011 DURLU-ÖZKAYA F, et al. This is an open-access article distributed under the terms of the Creative Commons Attribution License, which permits unrestricted use, distribution, and reproduction in any medium, provided the original author and source are credited. 
Seed oil is also taken orally as a laxative and applied externally as an emollient and pectoral [23]. Decoction of dried leaves is taken orally for diabetes [24]. Tincture of leaves is taken orally as a febrifuge [25]. Fruit is applied externally to fractured limb [26]. Fruit is used externally as a skin cleanser [27]. Hot water extract of dried plant is taken orally for bronchial asthma [28]. Infusion of the fresh leaf is taken orally for as an anti-inflammatory [29]. They include:

- Interfering with certain amino acid production processes necessary to keep the pathogen alive.

- Inactivating viruses by interfering with virus shedding, budding or assembly at the cellular membrane.

- Neutralizing retrovirus by preventing production of the viral enzymes, reverse transcriptase and protease needed by the retrovirus to alter the RNA of a healthy cell. This is true for the Human Immunodeficiency Virus (HIV).

- Stimulating phagocytosis, immune system response in which macrophages ingest microorganisms and foreign substances [30].

The reported benefits of olive leaf extract's range from promoting increased energy and healthy blood pressure, to supporting the cardiovascular system, and the immune system.

\section{Hypoglycemic and hypolipidemic activities}

The olive leaf could have a significant effect on the management of blood sugar levels. The hypoglycemic activity of olive leaf was studied by several authors. Studies in laboratory animals have shown hypoglycemic and hypolipidemic activity of olive leaf [31,32]. In diabetes mellitus, various hypoglycemic agents reduce oxidative stres indirectly by lowering blood glucose level and preventing hyperinsulinemia and directly by acting as free radical scavengers. Oleuropein has been reported with an effective hypoglycemic action in diabetic animals [9]. One of the other compounds responsible for hypoglycemic activity was oleuropeoside, which showed activity at a dose of $16 \mathrm{rug} / \mathrm{kg}$. This compound also demonstrated antidiabetic activity in animals with alloxan-induced diabetes. The hypoglycemic activity of this compound may result from two mechanisms:

(a) potentiation of glucose-induced insulin release, and

(b) increased peripheral uptake of glucose [32].

The hypoglycemic activity of olive leaf has been demonstrated in animals. In rabbits with induced diabetes, an ethanol extract of olive leaf decreased blood glucose or blood sugar levels, by working independently of insulin to increase metabolic uptake of glucose. However, this activity is believed to be in concert with the glucoseinduced insulin release [32]. A comparison was made between the action of olive leaf extract and an antidiabetic drug, which is called glibenclamide, and it was claimed that the antidiabetic effect of the extract was more effective than that observed with glibenclamide [31]. These results have not been reproduced in human clinical trials.

\section{Thyroid activities}

Studies in laboratory animals have reported thyroid activity of olive leaf extract. The aqueous extract of olive leaf administered to rats for 14 days increased T 3 levels and reduced circulating thyroid-stimulating hormone levels, possibly via a feedback mechanism [33].

\section{Cardiovascular disorders}

Epidemiological data obtained from clinical studies have consistently demonstrated that the Mediterranean diet, rich in olive oil, fruits, vegetables, and grains is correlated with a lower than average risk of coronary heart disease [34]. The natural antioxidants, including oleuropein, from the olive tree may play a role in the prevention of cardiovascular diseases through a decreased formation of atherosclerotic plaques by inhibiting LDL oxidation [35]. Some researchers search out in vivo study that evaluated oleuropein's effects on the serum low density lipoprotein (LDL) levels in animals. Studies were carried out on the basis of the positive results obtained with in vitro and some of them in pilot studies on human LDL. The results of these pilot studies indicated that certain constituents in olive oil inhibited prooxidative processes in human LDL. The cholesterol lowering effects of olive leaf extracts are thought to come from oleuropein, a substance contained within the leaf. Studies on hypercholesterolemic rats have shown that olive leaf extracts are more effective at lowering cholesterol than pure oleuropein $[36,37,38]$.

Additionally oleuropein was displayed in a laboratory study to have a clear ability to promote healthy dilatatory action in coronary arteries. Also traditional uses support olive leaf and olive oil in cardiovascular disease prevention [39,40]. Animal experiments in rabbit and rat preparations found a hypotensive effect of oleuropein, possibly via direct action on smooth muscle. Oleuropeoside also may exert vasodilator activity. Additionally, olive leaf extracts may possess antispasmodic, vasodilator, and anti-arrhythmic properties [41].

\section{Olive leaf extract and high blood pressure}

Hypertension is one of the most common and important disease factors caused by the modern lifestyle, in particular by reduced physical activity and an unbalanced, lipid-rich diet. In usual, the treatment of hypertension is aimed at an early diagnosis followed by adequate lifestyle changes rather than pharmacological treatment [38].

Olive leaf has a wide number of constituents, including oleuropein and several types of flavonoids (e.g., rutin, apigenin, luteolin). While olive leaf is traditionally associated with a wide number of medicinal claims, few of these have been verified by experimental study. In a number of animal study oleuropein (when given by injection or in intravenous form) was found to decrease blood pressure (e.g., systolic and diastolic). This ability to lower blood pressure may justify the traditional use of olive leaf in the treatment of mild to moderate hypertension. However, human studies are needed to clearly establish olive leaf as a potential treatment for high blood pressure [42]. With this respect, a prophylactic blood pressure lowers and cholesterol lowers actions of the olive leaf extract $\mathrm{EFLA}^{\circledR} 943$ in human was studied by Perrinjaquet-Moccetti et al. [38]. The study confirmed the antihypertensive and cholesterol lowering actions of the extract in human [38].

\section{Increased energy level with using olive leaf extract}

One of the most frequent comments heard from patients after taking olive leaf extract is that they experience a dramatic increase in energy levels and have a greater sense of well-being. Also it is the fact that many of the patients want to continue taking olive leaf extract even after their treatment program has taken care of specific problems. Improvement in energy levels can also be seen specifically in "fatigue" type disorders, such as chronic fatigue syndrome, lupus, mononucleosis, etc. Most doctors would consider abnormal fatigue levels to be the number one complaint heard from patients. It is pointed out that if these people would improve their dietary and exercise habits, they would all experience some improvement in energy levels and 
reducing fatigue. However, olive leaf represents an easy way to quickly fight the problem [38].

\section{Antibacterial effect}

Olive leaves are known to resist insect and microbial attack, and in-vitro studies have been conducted to establish the range of activity of olive leaf extracts $[43,44,45]$. Olive leaf extract contains some special compounds called flavonoids, which possess anti-inflammatory abilities. Oleuropein is able to work against microorganisms. From research and clinical experience to date, it can be say that supplemental olive leaf may be beneficial in the treatment for conditions caused by, or associated with, a virus, retrovirus, bacterium or protozoan. When unheated olives are brined to preserve them, oleuropein is converted into elenoic acid in the body which may prevent viruses and bacteria from replicating. Elenolic acid has shown antibacterial actions against several species of Lactobacilli and Staphylococcus aureus and Bacillus cereus in a test tube study [46-49]. Olive leaf extract has been reported to be an effective antimicrobial agent against a variety of pathogens, including Salmonella Typhi, Vibrio parahaemolyticus, Staphylococcus aureus (including penicillin-resistant strains); Klebsiella pneumonia and Escherichia coli, causal agents of intestinal or respiratory tract infections in humans [43,50]. Additionally olive leaf extract has been shown to be effective against the following microorganisms: Pseudomonas aeruginosa, Trichophyton mentagrophytes, Microsporum canis, T. rubrum and Candida albicans. Olive leaf could be considered a potentially effective antimicrobial agent for the treatment of intestinal or respiratory tract infections. The component usually associated with olive leaf s antimicrobial properties is oleuropein $[1,51]$.

As recently as 1998, researchers investigated oleuropeins' antibacterial action and concluded that it can enhance nitric oxide production in mouse macrophages. By increasing nitric oxide production, oleuropein appears to arm the macrophages against endotoxins (bacterial poisons generated by gram-negative bacteria). Interestingly, oleuropein only increased nitric oxide production when endotoxins were present $[5,38]$.

\section{Antiviral effect}

Olive leaf may be a true anti-viral compound because it appears to selectively block an entire virus-specific system in the infected host. Its' antiviral activity caused by the constituent calcium elenolate; a derivative of elenolic acid $[49,52]$. The isolated calcium salt of elenolic acid was tested as a broad-spectrum antiviral agent active against all viruses tested $(53,54)$. Some viruses inhibited by calcium elenolate in vitro include rhinovirus, myxoviruses, Herpes simplex type I, Herpes simplex type II, Herpes zoster, Encephalomyocarditis, Polio 1, 2, and 3 , two strains of leukemia virus, many strains of influenza and parainfluenza viruses $[49,55]$.

Action mechanism of the antiviral activity of the olive leaf's includes an ability to interfere with critical amino acid production for viruses; an ability to contain viral infection and/or spread by inactivating viruses by preventing virus shredding, budding or assembly at the cell membrane; the ability to directly penetrate infected cells and stop viral replication. In the case of retroviruses, it is able to neutralize the production of reverse transcriptase and protease and stimulation of phagocytosis. Anti-HIV properties of olive leaf extract include upregulation of the expression of apoptosis inhibitor proteins as well as protein kinase signaling molecules [38].

Many studies have specifically targeted olive leaf extract's ability to light the common cold, flu, and other related conditions, and have demonstrated amazing results. One of such study, conducted by researchers at the R Clinic in Budapest, Hungary, found that treatment with olive leaf extract helped over 90 percent of 164 patients with respiratory and lung conditions [38].

Renis (1975) was reported that calcium elenolate inhibited a number of viruses, including parainfluenza, herpes, pseudorabies, vesicular stomatitis, encephalomyocarditis, Newcastle disease, some forms of polio, and Sindbis. Every virus exposed to calcium elenolate, except for reovirus and poliovirus, were inactivated [49].

\section{Anti-fungal, anti-yeast and anti-parasitic effects}

Numerous studies show that a significant cause of most common health concerns involves infection by parasites, fungi and yeasts. These organisms can infect nearly every area of the body. Fungi are survivors and alter their growth to suit their environments, but cannot overcome a healthy immune system. They are frequently found among patients with AIDS, cancer and diabetes, athletes, elderly individuals, people who spend considerable time standing or who wear the same shoes day after day, or who wear artificial fingernails. Drugs taken for many other conditions lower resistance and are believed to make people more susceptible to infection. Fungi can infect dead material; additionally they also can infect living animals. Olive leaf has been shown to be effective against these fungi. Candida albicans, Candida krusei, oral candidiasis are some of them. More over it has also effective against cryptosporidia, giardia, pinworms, tapeworms, ringworm, malariacausing protozoa, and many others $[10,38]$.

\section{Antioxidant effect}

Most scientists and researchers familiar with olive leaf extract recognize oleuropein as its major component responsible for a variety of health benefits in humans. One of these benefits is that of combating free radical damage to individual cells $[56,57]$. Olive leaf has frequently claimed as a part of nutritional supplements or functional foods or even as a complement for the treatment of certain diseases [58]. Olive leaf has antioxidant properties associated with oleuropein. Oleuropein, hydroxytyrosol, and extracts of Olea europaea leaf (containing 19\% oleuropein, $1.8 \%$ flavonoid glycosides, and 3,4-dihydroxy-phenethyl esters) were more potent antioxidants than vitamin $\mathrm{E}$ or another established antioxidant, in a model chemical system [59]. Oleuropein, as an antioxidant, has been reported to decrease the oxidation of low-density lipoproteins (LDL) cholesterol [60]. Oxidized LDL is the most damaging form of cholesterol and can initiate damage to arterial tissues, thereby promoting atherosclerosis [36]. In-vitro and animal experiments have been demonstrated the antioxidant activity of olive leaf extracts. In rat epithelial cells stimulated with cytokines, a concentrated polyphenol extract reduced nitrite concentration and free radical production. Rabbits with induced diabetes showed a decrease in oxidative stress markers when treated with oleuropein [37]. Other experiments support the antioxidant activity of the phenols oleuropein and hydroxytyrosol [59].

Over all it is also indicated that skin damage caused by acute ultraviolet B (UVB) irradiation searched in mice by several authors. Olive leaf extract and oleuropein treatments inhibited the increases in skin thickness of mice induced by radiation [61].

\section{Oleuropein as an additive for feed}

Oleuropein appears to be present throughout the olive tree. Several residual products gain in during the olive oil production. All these byproducts can be improved through industrial process, chemical agent 
treatments and ensilage to increase the feeding value. All of them may be described as below [62]:

- Crude olive cake is the residue of the first extraction of the oil pressure from the olives,

- Exhausted olive cake is the residue from the solvent extraction of the crude olive cake,

- Partly destoned olive cake is residue from the partial separation of the stone from the pulp by screening or ventilation,

- Vegetation water is the liquid obtained during oil manufacturing and separated by centrifugation or sedimentation after pressing,

- Leaves and prunings are the branches, twigs and leaves obtained after pruning or at the oil mill.

Olive crop and derived industries are economically and socially very important in Mediterranean countries. Significant amounts of small branches and oliveleaves are generated during cleaning of olives. This is traditionally used in Mediterranean countries as an alternative source of nutrients for small ruminants during periods of scarce feed supplies as growth promoters $[63,64,65]$. In another aspect, an additive is provided that improves weight gain and feed conversion in production animals and has positive effects on the health of both production animals and pets. Furthermore, the inventive additive improves the quality of animal products such as milk and meat $[62,66]$.

The use of antibiotic or chemotherapeutic substances as growth promoters, in the production of livestock is well known [67]. In recent years attention has focused on problems related to the widespread use of antibiotics or chemotherapeutics as growth promoters. As it is known, there is a risk for residues of antibiotics, especially used both in animals and humans, are left in animal products consumed by humans. Additionally, consumption of antibiotic-resistant microorganisms through animal products is another risk for human. Furthermore, use of chemotherapeutic growth promoters has shown to be causing cancer $[68,69]$. As a result of all those, it has banned the use of classical growth promoters in EU countries by the end of 2005 [69].

Utilization of olive leaves and some products of it as sheep and goats fed diets carried out by many researchers $[63,65,70]$. It is well known that olive leaves contain various functional and/or antibacterial substances. These active substances are caused by their antioxidative characteristics. Antioxidants protect the cells against degradation and harmful substances, reduce the risk of infection, and have a special effect in intensive production systems and stress situations. The antioxidative activity from the active substances found in olive is far more effective than a synthetic form of vitamin E [71].

Different studies carried out with olive leaves reflected a low nutritive value [65]. The low nutritive value of this olive by-product could be explained by the presence of phenolics such as tannins, which may limit nutrient availability $[64,72,73]$ due to their capacity to bind proteins and carbohydrates [74]. It was pointed out that improving of olive leave nutritive value may be supplemented by proteins [64]. This new product could be an interesting source of nutrients for livestock [64] since the scarcity of conventional feedstuffs in Mediterranean countries represents a limitation for animal production development. Delgado-Pertinez et al. (1998), informed that the use of olive tree foliage as feed in animal production systems is a common practice in the Mediterranean basin. They have also mentioned that the effect of storage on crude protein and organic matter digestibility and on the concentration of Oleuropein of leaves was less dramatic and due largely to the loss of cell contents [75].
Effects of procedures of milling and milling-screening on feed value of dried olive-cake were also investigated. It was pointed out that the milling procedure did not affect feed value of dried olive-cake while the milling-screening procedure increased it [76]. Martín-García et al. (2004) were studied the ruminal fermentation characteristics of the two-stage dried olive cake inoculated with rumen liquor from goats or sheep. Two-stage dried olive cake fermentation promoted low volatile fatty acid production, predominantly acetic acid, and low efficiency of low volatile fatty acid production [77].

However, no information is available concerning in vivo ruminal environment promoted by olive leave fermentation. This point of view would be of importance to learn the true potential of olive leave as alternative forage. Some studies searched in vitro $[64,78]$ showed that use of olive leave nutrients could be limited by phenolic compounds, such as condensed tannins.

Silanikove et al. (1994) indicated that the use of compounds such as polyethylene glycol (PEG), which seems to dissociate the tanninprotein complexes, could help to clarify the presence and effects of tannins in two-stage olive cake on ruminant digestion [79]. Since it has been reported that sheep and goats have a different capacity for adapting to diets containing tannins [79], a comparative study of the inoculum source is relevant to state the value of the new two-stage olive cake for the two ruminant species. In addition, the nutritive value of lignocellulosic feedstuffs may often be improved by adding supplementary nitrogen. The suitability of different forms of nitrogen to be used with lignocellulosic materials in promoting improved digestion is of great interest. Nevertheless, it is still lacking in clarity, especially related to the aptness of using protein or non-protein nitrogen $[80,81]$.

As a sum, using of the oleuropein as a feed additive for production of domestic animals has at least the following beneficial effects:

Used as a feed additive, an antioxidative effect in the animal by protecting against degradation of cells, reducing the usage of other antioxidants, e.g. vitamin $\mathrm{E}$ and selenium, and protection against heat stress. Improvement of productivity and health status in animals by having antimicrobial and antiviral properties, improving feed conversion, improving the utilization of nutrients, improving health status by protecting the epithelial cells in the gastrointestinal tract, stimulate the animals' immune system as well as improve immune response to vaccination and thereby protect against stress related diseases or a production decline, strengthen especially the smallest and weakest animals and achieve a more homogeneous production.

Improvement of product quality by improvement of the waterholding properties (reduction of drip loss) by protecting the cell membranes, improvement of the meat color by delaying the pigment, oxidation from the red oxymyoglobin to the brown metmyoglobin, improvement of the stability of the fatty acids, and thereby the shelf life of the meat, by delaying lipid oxidation through the antioxidative activity of the product, and improvement of meat quality by lowering the risk of developing PSE (pale, soft and exudative) by stress reduction. The inventive additive is believed to have a considerable effect on the livestock's health, production efficiency, feed intake, daily weight gain and feed utilization. It is further believed that the inventive additive reduces the usage of other antioxidants such as vitamin $\mathrm{E}$ and selenium in production animals and pets, has antimicrobial and antiviral characteristics, improves nitrogen utilization, and improves the nutrient substance utilization generally [69]. Conia et al. [82] found that, the addition of oleuropein in the standart diet for rabbits increased the ability of LDL tp resist oxidation and at the same time, reduced 
the plasmatic levels of total, free and ester cholesterol, giving rise to a redistribution of the lipidic components of LDL with an indirect effect on their dimension [82].

\section{Conclusion}

To sum up, plants have been used as medicines since the time of immemorial, among which is Olea europaea whose products are widely available in the market for the treatment of various complaints. The active ingredient of the plant is called oleuropein; it is this component that is responsible for its therapeutic benefits for human and animals. It has efficacy in the management of various complex diseases including diabetes, cardiovascular disorders, viral and microbial infections but still a lot of work is to be done for appraisement the evidences for other traditional uses of the plant. Although there are some products added Oleuropein accepted by FDA (US Food and Drug Administration), there is no any products added olive leaves accepted by FDA or WHO (World Health Organization). Oleuropein is the principal phenolic compound in olive and its concentration changes significantly during fruit development (minimum in maturation) [83]. Additionally characteristic olive leaf extract with a high content of oleuropein and active polyphenols like flavonoids, oleuropeosides and substituted phenols show a synergic behaviour inmixed form [84].

Animal and olive production should therefore be integrated as has been done traditionally in many regions of the Mediterranean Basin. Such integration would be profitable to both the animal and plant sectors. The animals would valorize by-products which constitute a lowcost feed but which would otherwise be wasted, while olive plantations in turn would receive the benefits of an organic fertilizer of which their soils are often badly in need. Soler-Rivas et al. [50] indicated that, the final content of Oleuropein and its transformation products depends on the processing methods [50].

\section{References}

1. Petkov V, Manolov P (1972) Pharmacological analysis of the iridoid oleuropein. Drug Res 22: 1476-1486.

2. de la Ribeiro R, de Melo F, de Barros F, Gomes C, Trolin G (1986) Acute antihypertensive effect in conscious rats produced by some medicinal plants used in the state of Sao Paolo. J Ethnopharmacol 15: 261-269.

3. Khayyal MT, el-Ghazaly MA, Abdallah DM, Nassar NN, Okpanyi SN,et al. (2002) Blood pressure lowering effect of an olive leaf extract (Olea europaea) in L-NAME induced hypertension in rats. Arzneimittelforschung 52: 797-802.

4. Puel C, Mathey J, Agalias A, Kati-Coulibaly S, Mardon J,et al. (2006) Doseresponse study of effect of oleuropein, an olive oil polyphenol, in an ovariectomy/ inflammation experimental model of bone loss in the rat. Clin Nutr 25: 859-868.

5. Visioli F, Bellosta S, Galli C (1998) Oleuropein, the bitter principle of olives, enhances nitric oxide production by mouse macrophages. Life Sci 62: 541-546.

6. Pinelli P, Galardi C, Mulinacci N, Vincieri F, Tattini M (2000) Quali-quantitative analysis and antioxidant activity of different polyphenolic zextracts from Olea europaea L. leaves. J Commodity Sci 39: 71-83.

7. Dembitsky VM (2005) Astonishing diversity of natural surfactants: 5 . Biologically active glycosides of aromatic metabolites. Biomed Life Sci 40: 869-900.

8. Harwood JL, Yaqoob P (2002) Nutritional and health aspects of olive oil. Eur J Lipid Sci Techn 104: 685-697.

9. Al-Azzawie HF, Alhamdani MS (2006) Hypoglycemic and antioxidant effect of oleuropein in alloxan-diabetic rabbits. Life Sci 78: 1371-1377.

10. Khan Y, Siddharth P, Niraj V, Amee B ,Vimal K (2007) Olea europaea: A PhytoPharmacological Review, Pharmacol Rev 1: 114-118.

11. Özkaya MT, Ergülen E, Ülger S, Özilbey N (2004) Genetic and Biologic Characterization of Some Olive (Olea europaea L.) Cultivars Grown in Turkey. Tarım Bilimleri Dergisi 10: 231-236.

12. Özkaya MT, Ulaş M, Çakır (2009) Zeytin ağacı ve zeytin yetiştiriciliği. s: 1-25. Editör: F. Göğüş, M.T. Özkaya, S. Ötleş, Zeytinyağı. Eflatun Yayınevi. Ankara.
13. Ozkaya MT, Turchia, Editör: M. Oreggia, L'Extravergine 2008 - The Guide to the World Best, Roma- Italya. 2008, pp 850.

14. Briante R, La Cara F, Febbraio F, Patumi M, Nucci R (2002) Bioactive derivatives from oleuropein by a biotransformation on Olea europaea leaf extracts.J Biotechnol 93: 109-119.

15. Samova LI, Shode FO, Ramnanan P, Nadar A (2003) Antihypertensive ,antiatherosclerotic and antioxidantactivity of triterpenoids isolated from Oleaeuropaea,subspecies Africana leaves. J Ethnopharmacol 84: 299-305.

16. Cioffi G, Pesca MS, De Caprariis P, Braca A, Severino L (2010) Phenolic compounds in olive oil and olive pomace from Cilento (Campania, Italy) and their antioxidant activity. Food Chem 121: 105-111.

17. Şanlıer N, Cömert M, Durlu-Özkaya F, Özkaya MT (2008) Awareness of consumers over effects of olive oil on human health. VI.International Symposium on Olive Growing. September 9-13 Evora-Portugal.

18. Durlu-Özkaya F, Cömert M, Şanlıer N, Özkaya MT (2008) Recognition and consumption of olive products. VI.International Symposium on Olive Growing. September 9-13 Evora-Portugal.

19. Durlu-Özkaya F, Türk Mutfağında Zeytinyagı Editör: F. Göğüş, M.T. Özkaya, S Ötleş, Zeytinyağı. (2009). Eflatun Yayınevi. Ankara 352-365.

20. Cömert M, Durlu-Özkaya F, Şanlıer N ve Ozkaya MT (2008) Determining Women Behaviour Over Olive Oil Usage. VI.International Symposium on Olive Growing. September 9-13 Evora-Portugal.

21. Bellakhdar J, Claisse R, Fleurentin J ,Yonos C (1991) Repertory of standard herbal drugs in the Moroccan. Pharmacop 35: 123-143.

22. Lawrendiadis $\mathrm{G}$ (1961) Conribution to the knowledge of the medicinal plants of Greece. Planta Med 9:164.

23. Al-Khalil S (1995) A survey of plants used in Jordanian traditional medicine. In J Pharmacol 33: 317-323.

24. Alarcorn-Aguilara FJ, Roman-Ramos R, Perez-Gutierrez S, Aguilar-Contreras A, Contreras-Weber CC (1998) Study of the anti-hyperglycemic effect of plan used as antidiabetics. J Ethnopharmacol 61: 101-109.

25. Gastaldo P (1974) Official compendium of the Italian flora XVI, Fitoterapia 45 199-217.

26. Ghazanfar SA, Al-Sabahi MA (1993) Medicinal plants of northern and centra Oman (Arabia). Econ Bot 47: 89-98.

27. Fujita T, Sezik E, Tabata M, Yesilada E, Honda G (1995) Traditional medicine in Turkey. VII, Folk medicine in middle and west Black Sea regions. Econ Bot 49: 406-422.

28. Vardanian SA (1978) Phytotherapy of bronchial asthma in medieval Armenian medicine. Ter Arkh 50: 133-136.

29. Pieroni A, Heimler D, Pieters L, Van Poel B ,Vlietnick AJ (1996) In vitro anticomplementary activity of flavonoids from olive (Olea europaea) leaves. Pharmazie 51: 765-768.

30. Kendall RV (2008) Olive leaf extract. Technical Bulletin, U.S. Animal nutritials of Vermont.

31. Eidi A, Eidi M, Darzi R (2009) Antidiabetic Effect of Olea europaea L. in Norma and Diabetic Rats Phytother Res 23: 347-350.

32. Zarzuelo MG, Gamez A, Utrilla MJ, Jimenez MP ,Osuna I (1992) Hypoglycemic activity of olive leaf. Planta Med 58: 513-515.

33. Al-Qarawi AA, Al-Damegh MA, ElMougy SA (2002) Effect of freeze dried extract of Olea europaea on the pituitary-thyroid axis in rats. Phytother Res 16: $286-287$

34. Kushi LH, Lenart EB,Willett WC (1995) Health implications of Mediterranean diets in light of contemporary knowledge. Meat, wine, fats, and oils. Am J Clin Nutr 61: 1416-1427.

35. Visioli F, Galli C (1994) Oleuropein protects low density lipoprotein from oxidation. Life Sci 55: 1965-1971.

36. Andrikopoulos NK, Antonopoulou S, Kaliora AC (2002) Oleuropein inhibits LDL oxidation induced by cooking oil frying by-products and platelet aggregation induced by platelet-activating factor. LWT-Food Sci Technol 35: 479-484.

37. Andreadou I, Iliodromitis EK, Mikros E, Constantinou M, Agalias A (2006) The olive constituent oleuropein exhibits anti-ischemic, antioxidative, and hypolipidemic effects in anesthetized rabbits. Am Soc Nutr J Nutr 136: 22132219. 
38. Perrinjaquet-Moccetti T, Busjahn A, Schmidlin C, Schmidt A, Bradl B (2008) Food Supplementation with an Olive (Olea europaea L.) Leaf Extract Reduces Blood Pressure in Borderline Hypertensive Monozygotic Twins Phytother. Phytother Res 22: 1239-1242.

39. Visioli F, Galli C (1998) The effect of minor constituents of olive oil on cardiovascular disease: new findings. Nutr Rev 56: 142-147.

40. Giugliano D (2000) Dietary antioxidants for cardiovascular prevention. Nutr Metab Cardiovas 10: 38-44.

41. Zarzuelo A, Duarte J, Jimenez J, Gonzalez M ,Utrilla MP (1991) Vasodilator effect of olive leaf. Planta Med 57: 417-419.

42. Khayyal MT, el-Ghazaly MA, Abdallah DM, Nassar NN, Okpanyi SN,et al.(2002) Blood pressure lowering effect of an olive leaf extract (Olea europaea) in L-NAME induced hypertension in rats. Arzneimittelforschung 52: 797-802.

43. Bisignano G, Tomaino A, Lo Cascio R, Crisafi G, Uccella N,et al. (1999) On the in-vitro antimicrobial activity of oleuropein and hydroxytyrosol. J Pharm Pharmacol 51: 971-974.

44. Federici F, Bongi G (1983) Improved method for isolation of bacterial inhibitors from oleuropein hydrolysis. Appl Environ Microb 46: 509-510.

45. Fleming HP, Walter WM, Etchells JL (1973) Antimicrobial properties of oleuropein and products of its hydrolysis from green olives. Microbiol 26: 777 782.

46. Tassou CC, Nychas GJE, Board RG (1991) Effect of phenolic compounds and oleuropein on the germination of Bacillus cereus T spores. Biotechnol Appl Bioc 13: 231-237.

47. Tranter HS, Tassou SC ,Nychas GJ (1993) The effect of the olive phenolic compound, oleuropein, on growth and enterotoxin B production by Staphylococcus aureus. J Appl Bacteriol 74: 253-259.

48. Renis HE (1970) In vitro antiviral activity of calcium elenolate. Antimicrob Agents Ch 167-168.

49. Renis HE (1975) Inactivation of myxoviruses by calcium elenolate. Antimicrob Agents Ch 8: 194-199.

50. Soler-Rivas C, Carlos JE, Wichers HJ (2000) Oleuropein and related compounds. J Sci Food Agric 80: 1013-1023.

51. Juven B, Henis $Y$, Jacoby B (1972) Studies on the mechanism of the antimicrobial action of oleuropein. J Appl Bacteriol 35: 559-567.

52. Heinze JE, Hale AH ,Carl PL (1975) Specificity of the antiviral agent calcium elenolate. Antimicrob Agents Ch 8: 421-425.

53. Soret MG (1969) Antiviral activity of calcium elenolate on parainfluenza infection of hamsters. Antimicrob Agents Chemoth 9: 160-166.

54. Efmorfopoulou E, Rodis P (2004) Complexation of oleuropein and transcinnamic acid with cyclodextrins. Chem Nat Compd 40: 362-366.

55. Hirschman S Z (1972) Inactivation of DNA polymerases of murine leukaemia viruses by calcium elenolate. Nat Cell Biol 238: 277-279.

56. Tripoli E, Giammanco M, Tabacchi G, Di Majo D, Giammanco S, et al.(2005) The phenolic compounds of olive oil: structure, biological activity and beneficial effects on human health. Nutr Res Rev 18: 98-112.

57. Hashim YZHY, Eng ME, Gill CIR, McGlynn H ,Rowland IR (2005) Components of olive oil and chemoprevention of colorectal cancer. Nutr Res Rev 63: $374-$ 386 .

58. Pérez-Bonilla M, Salido S, van Beek TA, de Waard $P$, Linares-Palomino PJ,et al. (2011) Isolation of antioxidative secoiridoids from olive wood (Olea europaea L.) guided by on-line HPLC-DAD-radical scavenging detection. Food Chem 124: 36-41

59. Oliveras-Lopez MJ, Berna G, Carneiro EM, Lopez-Garcia H, de la Serrana,et al. (2008) An extra-virgin olive oil rich in polyphenolic compounds has antioxidant effects in of mice. J Nutr 138: 1074-1078.

60. Stupans I, Kirlich A, Tuck KL, Hayball PJ (2002) Comparison of radical scavenging effect, inhibition of microsomal oxygen free radical generation, and serum lipoprotein oxidation of several natural antioxidants. J Agric Food Chem 50: $2464-2469$

61. Sumiyoshi M and Kimura $Y$ (2010) Effects of Olive Leaf Extract and its Main Component Oleuroepin on Acute Ultraviolet B Irradiation-induced Skin Changes in C57BL/6J Mice Phytother Res 24: 995-1003.
62. Sansoucy R (1985) Olive By-Products for Animal Feed/F2795 (Fao Animal Production and Health Paper). No: 43, Food and Agriculture Organization of the United Nations Rome. FAO

63. Delgado PM, Gómez CA, Garrido A (2000) Predicting the nutritive value of the olive leaf (Olea europaea): Digestibility and chemical composition and in vitro studies. Anim Feed Sci Technol 87: 187-201.

64. Martín GAI, Moumen A, Yáñez Ruiz DR ,Molina Alcaide E (2003) Chemica composition and nutrients availability for goats and sheep of two-stage olive cake and olive leaves. Anim Feed Sci Tech 107: 61-74.

65. Yáñez-Ruiz DR, Molina-Alcaide E (2008) A comparative study of nutrients utilization, alkaline phosphatase activity and creatinine concentration in the serum of sheep and goats fed diets based on olive leaves. J Anim Physiol Anim Nutr 92: 141-148.

66. Nielsen BKK, Elgaard T (2006) Natural antioxidative additive for feed and products used for humans, Worl Intellectual Property Organization Patent Scope, Pub. No: WO/2006/061021.

67. Thomke S, Elwinger K (1998) Growth promotants in feeding pigs and poultry mode of action of antibiotic growth promotants. Annales de Zootechnie 47: 153167.

68. Phillips I, Casewell M, Cox T, De Groot B, Friis C,et al. (2004) Does the use of antibiotics in food animals posea risk to human health? A critical review of published data. J Antimicrob Chemoth 53: 28-52.

69. Elgaard T, Nielsen BKK (2004) Natural antioxidant additive for feed and drinking water European Patent EP1419701.

70. Alcaide MD, Yáñez Ruiz E, Moumen A, Martín GI (2003) Chemical composition and nitrogen availability of some olive by-products. Small Ruminant Res 49 : 329-336.

71. Owen RW, Giacosa A, Hull WE, Haubner R, Spiegelhalder B, et al.(2000) Oliveoil consumption and health: the possible role of antioxidants. Lancet Oncol 1 : 107-112.

72. Aerts RJ, Barry TN, McNabb WC (1999) Polyphenols and agriculture: Beneficia effects of proanthocyanidins in forages. Agr Ecosyst Env 75: 1-12.

73. Silanikove N, Perevolotsky A , Provenza FD (2001) Use of tannin-binding chemicals to assay for tannins and their negative postingestive effects in ruminants. Anim Feed Sci Tech 91: 69-81.

74. Silanikove N, Shinder D, Gilboa N, Eyal, M Nitsan Z,et al.(1996) Binding of polyethylene glycol to samples of forage plants as an assay of tannins and their negative effects on ruminal degradation. J Agric Food Chem 44:3230-3234.

75. Delgado-Pertínez M, Chesson A, Provan GJ, Gcarrido A, Gómez-Cabrera A (1998) Effect of different drying systems for the conservation of olive leaves on their nutritive value for ruminants. Annu Zootechnol 47: 141-150.

76. Filya İ, Hanoğlu H, Canbolat Ö ve Sucu E (2006) Kurutulmuş pirinanın yem değeri ve kuzu besisinde kullanılma olanakları üzerinde araştırmalar 1. Yem değerinin in situ yöntemle belirlenmesi. Uludag Üniversitesi Ziraat Fakültes Dergisi 20: 1-12.

77. Martín GAI, Yáñez-Ruiz DR, Moumen A ,Molina-Alcaide E,et al.(2004) Effect of polyethylene glycol, urea and sunflower meal supply on two-stage olive cake fermentation. Anim Res 53: 245-257.

78. Molina-Alcaide E, Yáñez-Ruiz DR, Moumen A, Martín-Garcia Al (2003) Chemical composition and nitrogen availability for goats and sheep of some olive by-products. Small Ruminant Res 49: 329-336.

79. Silanikove N, Nitsan Z, Perevolotsky A (1994) Effect of polyethylene glyco supplementation on intake and digestion of tannin-containing leaves (Ceratonia siliqua) by sheep. J Agric Food Chem 42: 2844-2847.

80. Carro MD, Miller EL (1999) Effect of supplementing a fibre basal diet with different nitrogen forms on ruminal fermentation and microbial growth in an in vitro semi-continuous culture system (RUSITEC) Brit J Nutr 82: 149-157.

81. Molina-Alcaide E, Weisbjerg MR, Hvelplund T (1996) Degradation characteristics of shrubs and the effect of supplementation with urea or protein on microbial production using a continuous-culture system. J Anim Physiol An N 75: 121-132.

82. Conia E, Di Benedettoa R, Di Pasqualea M, Masellab R, Modestib D, et al (2000) Protective Effect of Oleuropein, an Olive Oil Biophenol, on Low Density Lipoprotein Oxidizability in Rabbits. Lipids 35: 45-54. 
Citation: DURLU-ÖZKAYA F, ÖZKAYA MT (2011) Oleuropein using as an Additive for Feed and Products used for Humans. J Food Process Technol 2:113. doi:10.4172/2157-7110.1000113

Page 7 of 7

83. Ryan D, Robards K, Lavee S (1999) Changes in phenolic content of olive during maturation. Int J Food Sciand Tech 34: 265-274.
84. Benavente-GarcõÂ O, Castillo J, Lorente J, OrtunÄ A, Del Rio JA, (2000) Antioxidant activity of phenolics extracted from Olea europaea $L$. Leaves. Food Chemistry 68: 457-462. 